DOI 10.18551/rjoas.2019-06.08

\title{
ASSESSMENT OF SAND LOBSTER (PANULIRUS HOMARUS) RESOURCES IN PALABUHANRATU WATERS OF SUKABUMI, WEST JAVA, INDONESIA
}

\author{
Suwartono Tomi \\ Master's Program in Marine Science, Faculty of Mathematics and Natural Sciences, \\ University of Indonesia, Indonesia \\ E-mail: tomeo37@yahoo.co.id
}

\begin{abstract}
Lobster fisheries resources are popular food commodities with high economic value. Consequently, lobsters are captured globally and have very high selling prices. Palabuhanratu Bay is one of the lobster fisheries centers in West Java, Indonesia. Sand lobster (Panulirus homarus), one of the lobster species in Palabuhanratu Bay, has experienced a decrease in the catch. This research aims to (1) examine the sand lobster population based on biological aspect and population dynamics aspect; (2) identify the utilization status and management of sand lobster resources. Population parameter was analyzed using the FISAT II program and Maximum Sustainable Yield (MSY) potential assessment. The results showed that sand lobster carapace length ranged between 30-101 $\mathrm{mm}$ with $97.6 \%$ carapace length below $8 \mathrm{~cm}$. The growth pattern of sand lobsters was negative allometric. The $L c<L r$ value indicated that female sand lobsters have been caught before reaching the mean size at onset of spawning. Asymptotic length $(L \infty)$ of male sand lobsters was smaller than female sand lobsters, while growth coefficient $(K)$ of male sand lobsters was faster than female sand lobsters. The rate of exploitation (E) values for male and female sand lobsters showed above optimum values of 0.59 and 0.61 . The sustainable potential and lobster resource utilization level in WPP 573 Waters was 662.93 tons/year and 910 thousand trips with nets as standard fishing gears. Catch fluctuated with a decreasing trend and the rate of exploitation above the optimum value. It indicated that overfishing has occurred.
\end{abstract}

\section{KEY WORDS}

FISAT II, sand lobsters, MSY, Panulirus homarus, Palabuhanratu Bay.

The high economic value of lobsters is one of the factors causing continuous lobster fishing with no attention to the resource and environmental conditions. Lack of awareness of fishery practitioners (communities, businesspersons, and fishermen) on the importance of environmentally-friendly fishing practices that can guarantee the sustainability of sea lobster stocks will damage lobster ecosystem and habitat, causing a reduction in the commodity stocks (Wardiatno and Mashar, 2013).

Palabuhanratu Waters is a potential waters with abundant fisheries resources and used as fishing areas for fishermen, one of which is lobster fishing. The high economic value of sand lobsters (Panulirus homarus) is one of the factors that encourage Palabuhanratu fishermen to conduct continuous fishing activities without regard to the resources and environmental sustainability. Fishermen are lack of awareness to control fishing as well, for example by regulating the number of catches and lobster fishing effort.

\section{LITERATURE REVIEW}

Palabuhanratu community identifies sand lobsters with the name of crayfish. Classification of sand lobsters according to Chan (1998) is:

Phylum: Arthropoda;

Subphylum: Crustacea;

Class: Malacostraca;

Order: Decapoda; 
Suborder: Macrura;

Family: Palinuridae;

Genus: Panulirus;

Species: Panulirus Homarus.

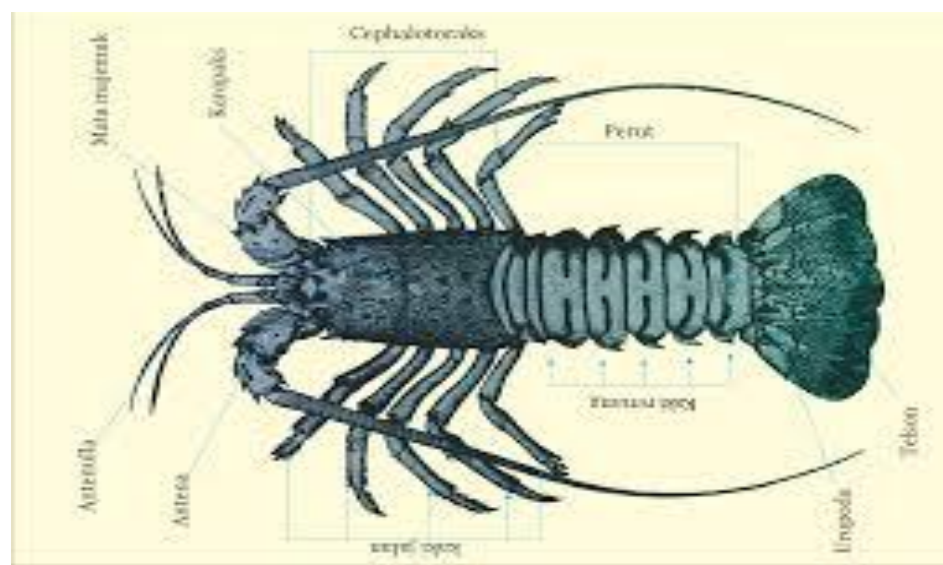

Figure 1 - Dorsal view of lobsters of the genus Panulirus (Source: WWF Indonesia, 2015)

In general, the growth rate of lobsters in the family Palinuridae ranges between 0.27 0.54 year. The asymptotic carapace length is quite diverse but generally ranges between 118-164 mm. The values of the growth rate and the asymptotic carapace length are used to determine the maximum lifespan of a lobster population. From some research results, the maximum lifespan of lobsters in the family Palinuridae ranges between 10-14 years (Kadafi et al., 2006). Cobb and Phillips (1980) state that lobsters are found mostly in coastal waters, especially on rocky bottoms or coral reefs, and sometimes on sandy bottoms mixed with aquatic plants. Adult lobsters generally molt and breed during the summer, so that a ban on lobster fishing during this period provides an opportunity for population development (Moosa MK and Aswandy I, 1984).

Population dynamics refers to how populations change in size over time. Population dynamic of lobster resources in waters is characterized by changes in population size both through additions and subtractions (Wijaya, 2007). In the balance of population dynamics, additions to the population can be caused by births, deaths, and migrations of lobster resources. According to Badrudin (2012), the catch per unit effort (CPUE) is a measure of relative abundance as one indicator of lobster resource status, while production levels can act as economic performance indicators. The CPUE trend of fisheries is an important indicator of fishery health.

Table 1 - Advantages and Disadvantages of Lobster Fishing Gears

\begin{tabular}{|l|l|l|}
\hline \multicolumn{1}{|c|}{$\begin{array}{c}\text { Name of Fishing } \\
\text { Gear }\end{array}$} & \multicolumn{1}{|c|}{ Advantages } & \multicolumn{1}{c|}{ Disadvantages } \\
\hline Trap & $\begin{array}{l}\text { Able to catch more lobsters than } \\
\text { krendet because trap has a bigger } \\
\text { chamber than krendet }\end{array}$ & $\begin{array}{l}\text { Need a bigger place when on a boat } \\
\text { The cost of making is more expensive than } \\
\text { krendet. }\end{array}$ \\
\hline Hook with Diving & More selective in terms of the catch. & $\begin{array}{l}\text { Able to threaten the health of the catcher when } \\
\text { diving }\end{array}$ \\
\hline $\begin{array}{l}\text { Krendet (hoop } \\
\text { net) }\end{array}$ & $\begin{array}{l}\text { The cost of making is cheaper } \\
\text { Easy to carry }\end{array}$ & $\begin{array}{l}\text { Fewer caught lobsters than trap } \\
\text { Able to damage habitat if left behind or stuck }\end{array}$ \\
\hline $\begin{array}{l}\text { Trammel Net or } \\
\text { Bottom-set Gillnet }\end{array}$ & $\begin{array}{l}\text { Able to catch a fairly large amount of } \\
\text { lobsters because the net is long and } \\
\text { stretched }\end{array}$ & $\begin{array}{l}\text { Less selective in catching because the net not } \\
\text { only catches lobsters but also another biota, such } \\
\text { as reef fish, etc. }\end{array}$ \\
\hline
\end{tabular}

Source: WWF Indonesia (2015). 


\section{METHODS OF RESEARCH}

The research location was the waters around Palabuhanratu, Sukabumi Regency, West Java Province (WPP 573). Palabuhanratu waters is located in the Indian Ocean region at the geographical position of $06^{\circ} 50^{\prime}-07^{\circ} 30^{\prime} \mathrm{S}$ and $106^{\circ} 10^{\prime}-106^{\circ} 30^{\prime} \mathrm{E}$. The preparation stage until the field survey was conducted from March to May 2018.

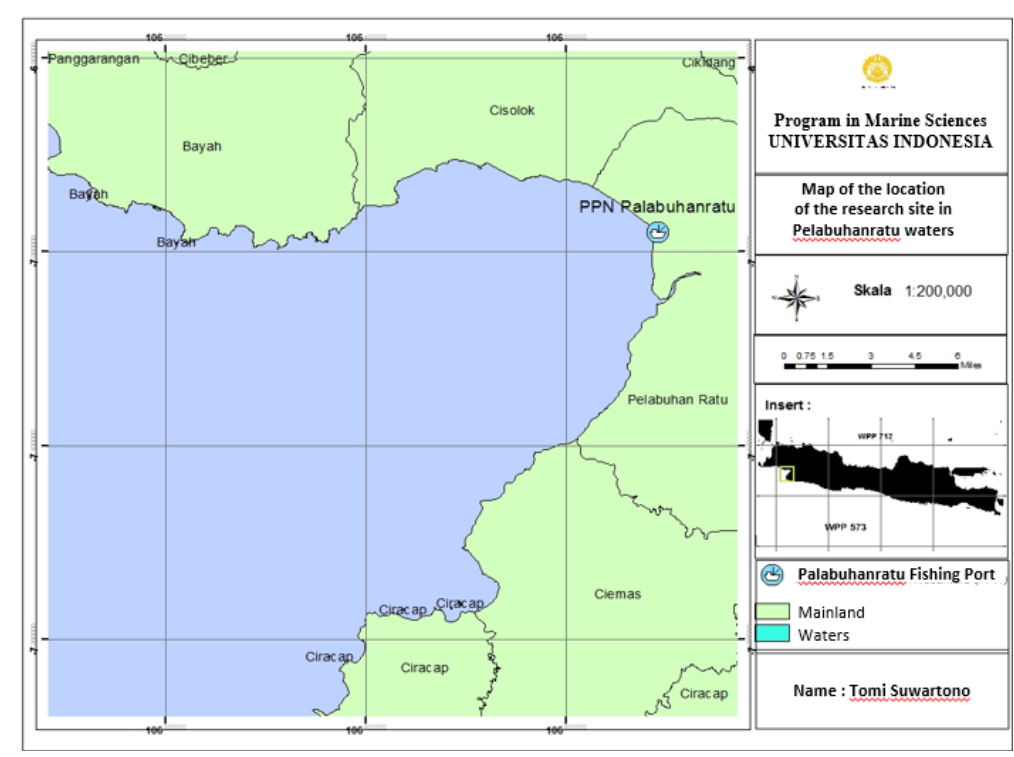

Figure 2 - Research Location in Palabuhanratu Bay Waters

Samples were observed for 3 months with data collection intervals once every two weeks using the census and simple random sampling method. The census method was utilized when the lobster catches were few that enabled thorough observation. Data measured included carapace length $(\mathrm{mm})$, weight $(\mathrm{mg})$, lobster sex, and the number of eggbearing lobsters. Lobster measurements were carried out on the species of $P$. homarus caught by previously selected fishermen. Carapace length of the lobsters used as the samples was measured using a caliper with a precision of $0.1 \mathrm{~mm}$ and weight was determined using a digital balance with a precision of $0.01 \mathrm{~g}$. Functional maturity of the female lobsters was observed by direct observation of the presence/absence of eggs under the abdomen (berried female). Primary data collection for economic aspects in this research was conducted using a structured interview method with a questionnaire list. In-depth interviews covered all aspects of production activities, including lobster selling prices and fishing operational costs, such as ships, machinery, fishing gear, fuel, and ship crew supplies.

Data on sand lobster carapace length were categorized into several length groups, so the $\mathrm{i}^{\text {th }}$ length group had a frequency. Estimation of the size group was conducted by analyzing the lobster carapace length frequency using the ELEFAN I (Electro Length Frequency Analysis) method with the FISAT II (FAO-ICLARM Stock Assessment Tool) program to determine lobster frequency distribution based on length and weight and lobster identification based on sex and gonad maturity. In addition, the growth and mortality rate of sand lobsters could also be examined through the curves produced by the FISAT II (FAOICLARM Stock Assessment Tool) program. Production and fishing armadas data were grouped and tabulated using Microsoft Excel to obtain the productivity value of fishing gear, Catch per Unit Effort (CPUE), fishing season, and Fishing Power Index (FPI). Thus, the utilization of sand lobsters in Palabuhanratu can be analyzed.

The length-weight relationship was calculated based on the following formula proposed by Effendie (1997); Fafioye and Oluajo (2005); and Kalayci et al. (2007):

$$
W=a L^{b}
$$


Where: $W=$ body weight; $L=$ fork length; $a$ and $b=$ constants.

The length at first capture value or the length at which $50 \%$ of a fish at first capture was calculated by the following formula (Sparre \& Venema, 1999 in Nuruludin and Sadhotomo, 2013).

$$
S L=\frac{1}{1+\exp ^{S 1-S 2 * L}}
$$

Where $S L=$ logistic curve; $\mathrm{L}=$ length interval midpoint; $\mathrm{S} 1$ and $\mathrm{S} 2$ = Constants.

Equation can be rewritten as:

$$
\begin{gathered}
\ln (1 / S L-1)=S_{1}-\mathrm{S}_{2} * \mathrm{~L} \\
L_{50 \%}=\frac{S_{1}}{S_{2}}
\end{gathered}
$$

The mean size at first gonad maturity $(\mathrm{Lm})$ was calculated using the Spearman-Karber formula developed by Udupa (1986) as follows:

$$
m=x_{k}+\frac{d}{2}-\left(d . \sum P_{i}\right)
$$

Where: $m=\log$ size of length groups at first maturity; $d=\log$ size increment; $k=$ number of length groups; $x k=$ last log size at which $100 \%$ of shrimp are fully mature $(\mathrm{Pi}=1)$. Thus, the length at first maturity was given by antilog equation.

Estimation of growth coefficient $(K)$ and asymptotic length $(L \infty)$ was obtained based on the Ford-Walford method (Sparre and Venema, 1999) by regressing lobster length at age $t$ $(\mathrm{Lt})$ with lobster length at age $\mathrm{t}+1(\mathrm{Lt}+1)$ which resulted in growth parameter equation $\mathrm{K}=-\mathrm{Ln}$ $b$ and $L \infty=a /(1-b)$. The t0 value or theoretical age of fish was calculated using Pauly's (1983) empirical formula of:

$$
\log \left(-t_{0}\right)=-0.3922-0.2752 \log L_{\infty}-1,038 \log K
$$

Estimation of growth parameters $(\mathrm{L} \infty$ and $\mathrm{K}$ ) used the FISAT (FAO-ICLARM Stock Assessment Tools) II version 1.2.2 program with the ELEFAN I (Electronic Length Frequency Analysis) method.

Von Bertalanffy growth model is as follows:

$$
L t=L^{\infty}\left(1-e^{-K\left(t-t_{0}\right)}\right)
$$

Where: $L t=$ lobster length at age $t ; L \infty=$ asymptotic length; $K=$ growth coefficient; $t=$ time.

The total mortality rate $(Z)$ was estimated using the Jones \& Van Zalinge method, while the natural mortality rate (M) was estimated using Pauly's (1984) empirical formula.

$$
\ln \mathrm{M}=-0,0152-0,279 \ln \mathrm{L} \infty+0,6543 \ln \mathrm{K}+0,463 \ln \mathrm{T}
$$

Where: $M=$ natural mortality; $L \infty=$ asymptotic length in the Von Bartalanffy growth equation; $\mathrm{K}=$ growth coefficient in the Von Bartalanffy growth equation; $\mathrm{T}=$ average water surface temperature $(0 \mathrm{C})$.

\section{RESULTS AND DISCUSSION}

Previous lobster research in Palabuhanratu Bay obtained a range of carapace length (CL) which was not significantly different from Zairion et al.'s (2017) research. Carapace length of lobsters caught using nets ranged between $28-100 \mathrm{~mm}$. 
Table 2 - Lobster production in WPP 573 Waters and Indonesian Waters

\begin{tabular}{cccc}
\hline \multirow{2}{*}{ Years } & \multicolumn{2}{c}{ Production (tons) } & \multirow{2}{*}{ Proportion (\%) } \\
\cline { 2 - 3 } & WPP 573 & Indonesia & 21.02 \\
2005 & 954 & 4,538 & 18.42 \\
2007 & 759 & 4,121 & 15.92 \\
2008 & 661 & 4,151 & 14.47 \\
2009 & 670 & 4,631 & 15.03 \\
2010 & 630 & 4,193 & 10.12 \\
2011 & 414 & 4,091 & 7.90 \\
2012 & 532 & 6,731 & 13.61 \\
2013 & 673 & 4,946 & 10.65 \\
2014 & 525 & 4,928 & 10.25 \\
\hline
\end{tabular}

Table 3 - Sex ratio of sand lobster (Panulirus homarus) every month of observation

\begin{tabular}{ccccc}
\hline Sampling Time & $\mathrm{n}$ & Male & Total & Sex \\
Ratio (M:F)
\end{tabular}

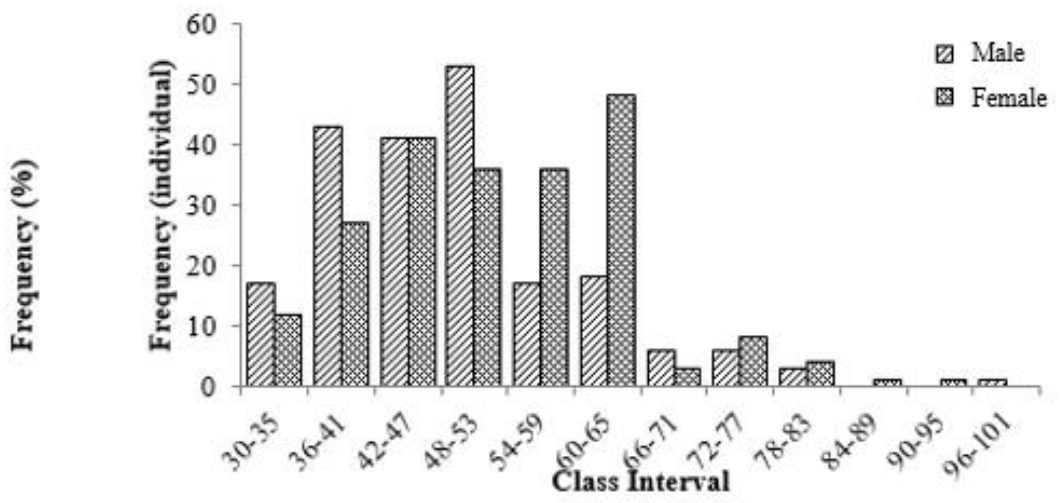

Figure 4 - Distribution of carapace length frequency of sand lobsters (Panulirus homarus) in Palabuhanratu Bay Waters

The carapace length-weight relationship of male and female lobsters obtained the coefficient of determination (R2) of 0.73 and 0.76 . It means the lobster carapace length influenced $73 \%$ of weight for male lobsters and $76 \%$ for female lobsters. The analysis results also obtained the growth pattern with the length-weight relationship of $W=0.0353 \mathrm{CL}^{2.0612}$ for male lobsters and $\mathrm{W}=0.0348 \mathrm{CL}^{2.0651}$ for female lobsters. It means male sand lobsters had a faster growth of carapace length than weight compared to female sand lobsters.

The ELEFAN I method in the FiSAT II program was used for age group analysis. The analysis results of the age groups of male sand lobsters and female sand lobsters indicated growth with an increase in the cohort line.

The mean length at first capture (LC) is the length at which $50 \%$ of the animals sampled are caught on the selectivity of fishing gear. The mean carapace length at first capture for male and female sand lobsters were $43.56 \mathrm{~mm}$ and $52.71 \mathrm{~mm}$ respectively. These research 
results were not significantly different from Zairion et al.'s (2017) research in which the mean carapace length at first capture (Lc) of male lobsters was $50.45 \mathrm{~mm}$ and female lobsters was $59.87 \mathrm{~mm}$. The size of the lobster catches results indicated high activity intensity condition in fishing activities and the high rate of exploitation.
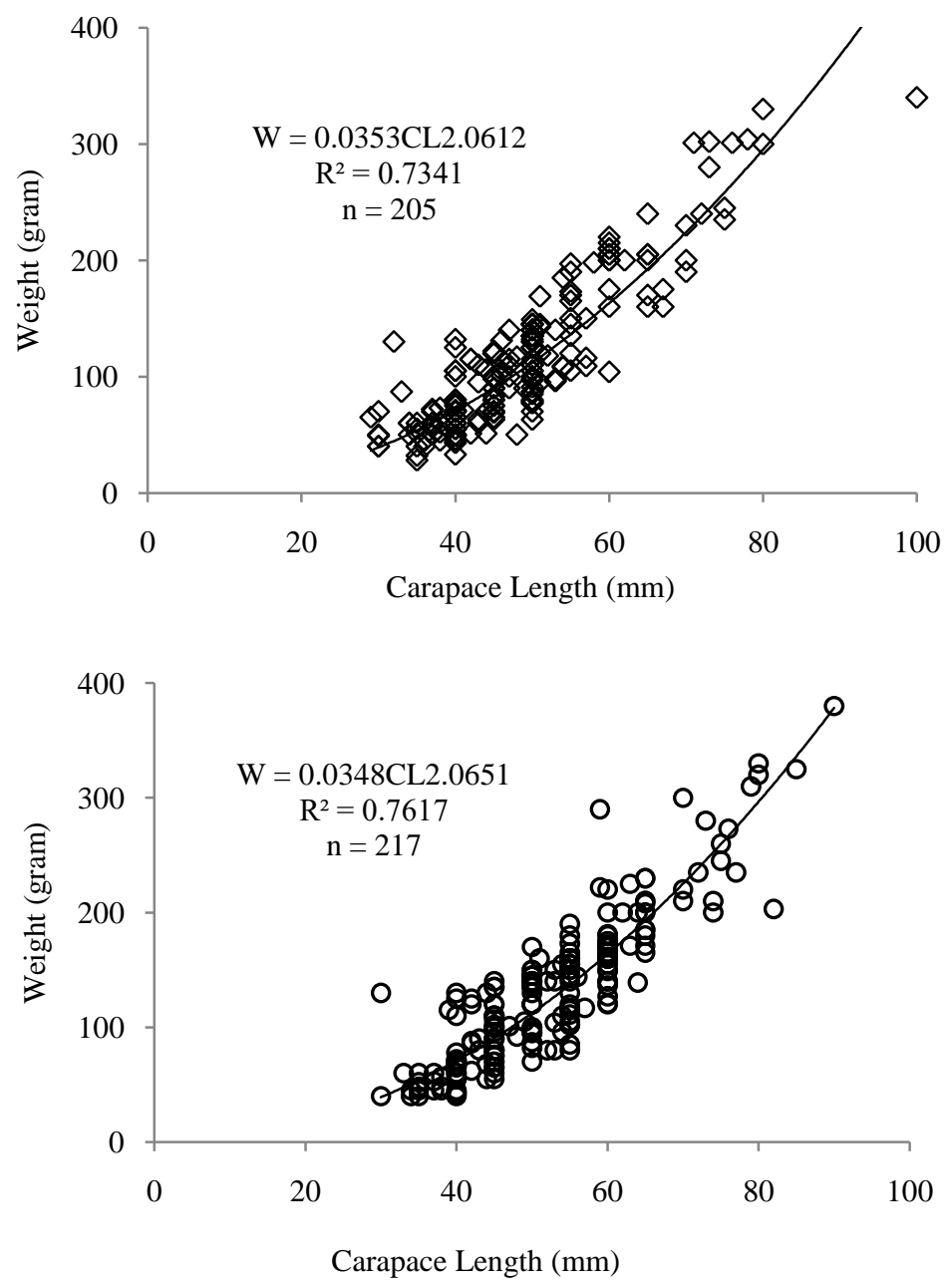

Figure 4 - The carapace length-weight relationship of sand lobsters in Palabuhanratu Bay:

(1) males and (2) females

This research found that the mean carapace length of female lobsters at onset of spawning was $72.75 \mathrm{~mm}$. The mean size at onset of spawning ( $\mathrm{Lr}$ ) in Palabuhanratu Bay in 2016 was $81 \mathrm{~mm}$ with a range between $80-82 \mathrm{~mm}$ (Zairion et al., 2017). In addition, Junaidi et al. (2010) stated that the value (Lr) on carapace length was $77.44 \mathrm{~mm}$.

The Von Bartalanffy growth equation of male and female sand lobsters resulted in $\mathrm{Lt}=$ $104,40\left(1-\mathrm{e}^{-0,33(t+0,3565)}\right)$ and $\mathrm{Lt}=108,90\left(1-\mathrm{e}^{-0,31(\mathrm{t}+0,3760)}\right)$. Male sand lobsters are estimated to live up to 8.73 years and female lobsters up to 9.30 years. The rate of exploitation (E) values for male and female sand lobsters showed above optimum values of 0.59 and 0.61 . Based on these values, it is estimated that overfishing has occurred on the sand lobster population in Palabuhanratu Bay.

Figure 7 generates a CPUE linear equation $=1.4565-0.0008 \mathrm{E}$ with the constant (a) of 1.4565. It means that when there is no effort, the available potential in nature is 1.4565 tons/effort.

The calculation results of the Schaefer model equation showed that $\mathrm{C}=1325.87 \mathrm{E}$ $0.7282 \mathrm{E} 2$. Potential estimation can be continued because the slope value was negative in which the value was a condition for determining MSY and FMSY. Based on the MSY value, the total allowable catch (TAC) for lobsters in WPP 573 was 530.34 tons/year. 

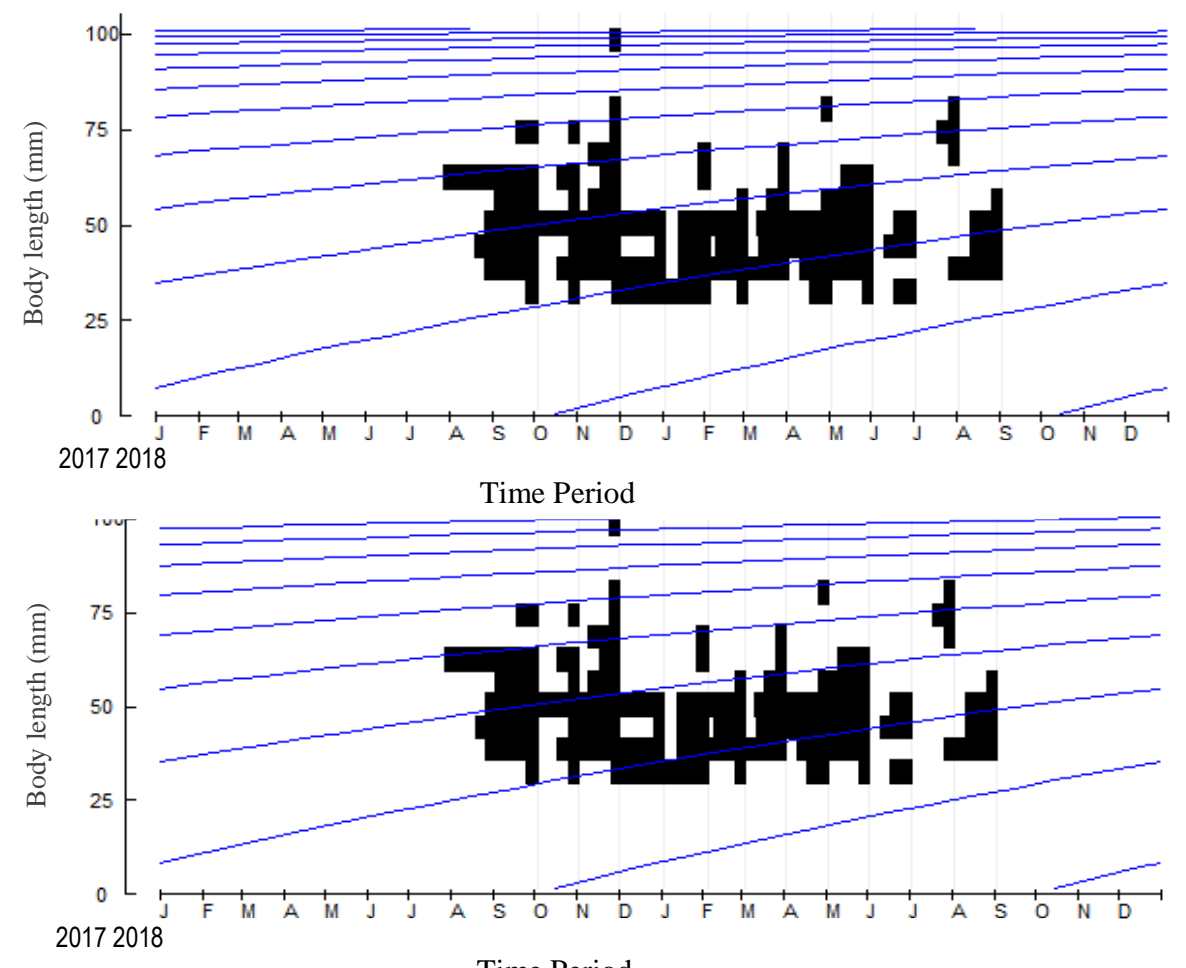

Time Period

Figure 5 - Distribution of carapace length frequency with the curve plot of von Bertalanffy's growth of sand lobsters (Panulirus homarus) in Palabuhanratu Bay Waters; (1) males and (2) females

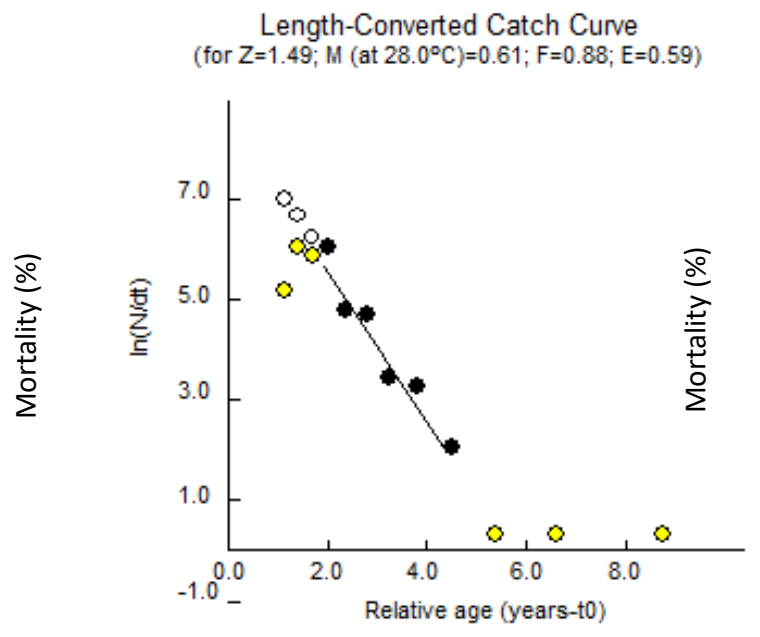

(a)

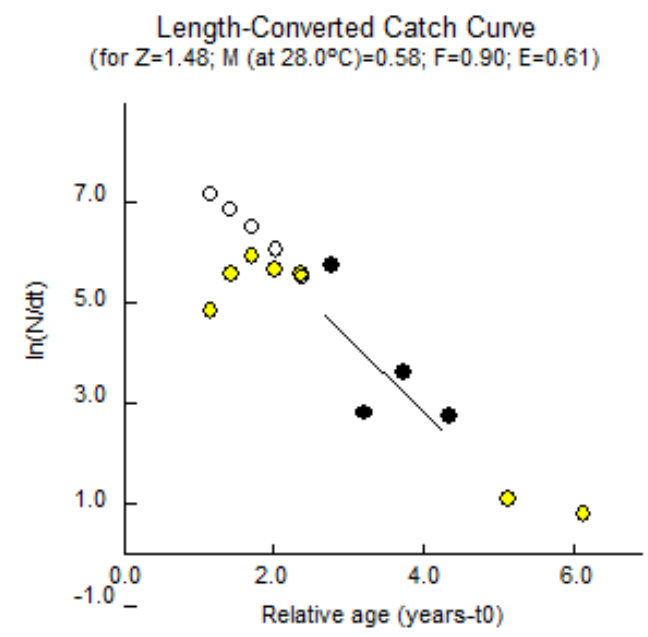

(b)

Figure 6 - Graph of total mortality $(Z)$, natural mortality $(M)$, capture mortality $(F)$, and rate of exploitation (E) of sand lobsters (Panulirus homarus) in Palabuhanratu Bay Waters based on the length-converted catch curve method: (a) males and (b) females

Table 4 - Production and Effort from Nets and Traps

\begin{tabular}{|c|c|c|c|c|}
\hline \multirow{2}{*}{ Year } & \multicolumn{2}{|c|}{ Effort } & \multicolumn{2}{|c|}{ Production (Ton) } \\
\hline & Nets & Traps & Nets & Traps \\
\hline 2005 & 670 & 320 & 763 & 191 \\
\hline 2006 & 714 & 345 & 592 & 167 \\
\hline 2007 & 740 & 369 & 502 & 159 \\
\hline 2008 & 801 & 283 & 536 & 134 \\
\hline 2009 & 778 & 260 & 504 & 126 \\
\hline 2010 & 698 & 218 & 331 & 83 \\
\hline 2011 & 581 & 206 & 399 & 133 \\
\hline 2012 & 496 & 232 & 538 & 135 \\
\hline 2013 & 538 & 255 & 424 & 101 \\
\hline 2014 & 671 & 230 & 333 & 102 \\
\hline
\end{tabular}


RJOAS, 6(90), June 2019

Table 5 - FPI Calculation for Traps and Nets as Standard Fishing Gears

\begin{tabular}{cccccc}
\hline \multirow{2}{*}{ Year } & \multicolumn{2}{c}{ CPUE $(\mathrm{C} / \mathrm{E})$} & \multicolumn{2}{c}{ CPUE Standardization } & \multirow{2}{*}{ FPI } \\
\cline { 2 - 5 } & Nets & Traps & Nets & Traps & 1.5234 \\
2005 & 1.1391 & 0.5963 & 1 & 0.5234 & 1.5837 \\
2006 & 0.8292 & 0.4840 & 1 & 0.5837 & 1.6333 \\
2007 & 0.6789 & 0.4299 & 1 & 0.6333 & 1.7076 \\
2008 & 0.6692 & 0.4735 & 1 & 0.7076 & 1.7481 \\
2009 & 0.6478 & 0.4846 & 1 & 0.7481 & 1.8010 \\
2010 & 0.4744 & 0.3800 & 1 & 0.8010 & 1.9401 \\
2011 & 0.6867 & 0.6456 & 1 & 0.9401 & 1.5345 \\
2012 & 1.0855 & 0.5802 & 1 & 0.5345 & 1.4997 \\
2013 & 0.7890 & 0.3943 & 1 & 0.4997 & 1.8912 \\
2014 & 0.4966 & 0.4426 & 0.8912 & \\
\hline
\end{tabular}

Table 6 - Catch and fishing effort of sand lobsters (Panulirus homarus) in WPP 573

\begin{tabular}{cccc}
\hline Year & C (Production) & Standard Effort & Standard CPUE \\
\hline 2005 & 954 & 838 & 1.1391 \\
2006 & 759 & 915 & 0.8295 \\
2007 & 661 & 974 & 0.6786 \\
2008 & 670 & 1001 & 0.6692 \\
2009 & 630 & 972 & 0.6481 \\
2010 & 414 & 873 & 0.4742 \\
2011 & 532 & 775 & 0.6865 \\
2012 & 673 & 620 & 1.0855 \\
2013 & 525 & 665 & 0.7895 \\
2014 & 435 & 876 & 0.4966 \\
\hline
\end{tabular}

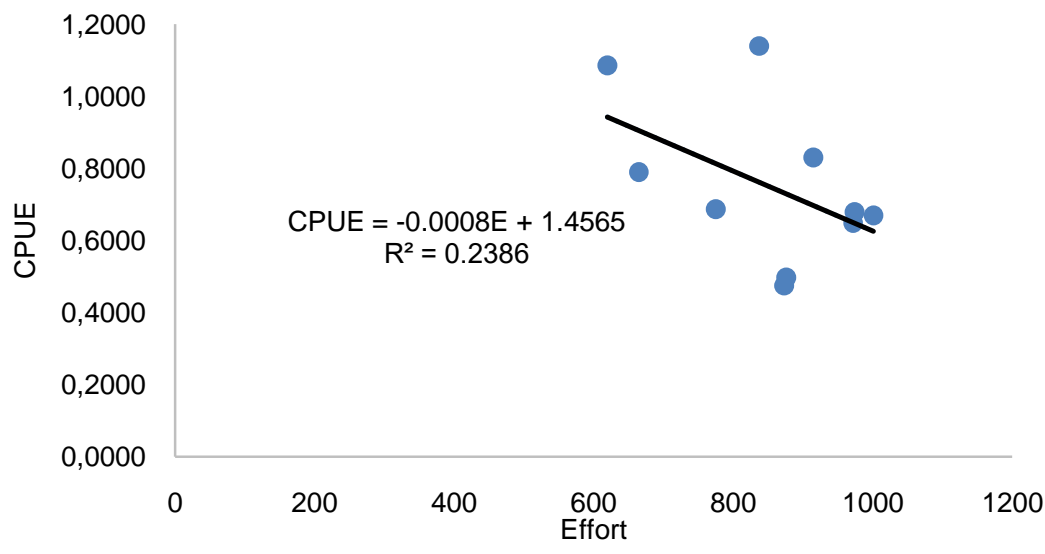

Figure 7 - Graph of the Standard Effort and Standard CPUE Relationship

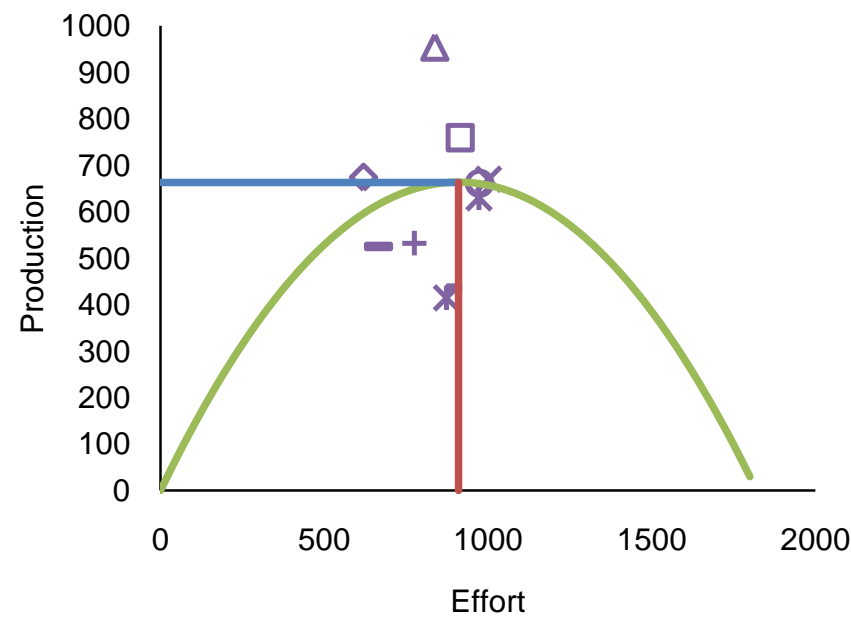

Figure 8 - MSY curve of sand lobsters (Panulirus homarus) in WPP 573 Waters 


\section{CONCLUSION}

Distribution of carapace length frequency of sand lobster (Panulirus homarus) in Palabuhanratu Waters ranged between $30-101 \mathrm{~mm}$ with $97.6 \%$ carapace length below $8 \mathrm{~cm}$. The growth pattern of male and female sand lobsters was negative allometric. Many female sand lobsters have been caught before reaching the mean size at onset of spawning. The rate of exploitation of sand lobsters was above the optimum value of lobster fishing. The status of lobster resources utilization in Palabuhanratu waters showed a decreasing utilization trend which indicated overfishing.

\section{REFERENCES}

1. Chan, T.Y. 1998. Lobster. In: Carpenter KE, Niem VH (eds.) FAO Species identification guide for fishery purposes. The living marine resources of the Western Central Pacific. Volume 2. Cephalopods, Crustaceans, Holothurians and Sharks. Rome: FAO. pp. 6871396.

2. Cobb, J. S., and Phillips, B. F. (1983). Behavior and distribution of larval and early juvenile Homarus americanus. Can. J. Fish. Aquat. Sci. 40: 2184-2188.

3. Effendie, M. I. 2002. Biologi Perikanan. Yogyakarta: Yayasan Pustaka Nusatama.

4. Kadafi, M., Widaningroem, R., \& Soeparno. 2006. Aspek biologi and potensi lestari lobster (Panulirus spp.) di perairan pantai Kecamatan Ayah, Kabupaten Kebumen. Jurnal Perikanan. 8(1): 108-117.

5. Moosa, M. K., \& Aswandy, I. 1984. Udang karang (Panulirus spp.) dari perikanan Indonesia. LONLIPI. Jakarta.

6. Pauly, D. 1984. Fish Population dynamics in tropical waters: a manual for use with programmable calculators. Manila: ICLARM.

7. Sparre, P., \& Venema, S. C. 1999. Introduksi Pengkajian Stok Ikan Tropis Buku emanual (Translated Edition). In cooperation between FAO UN and Center of Fisheries Research and Development, Badan Penelitian and Pengembangan Pertanian, Jakarta, Indonesia.

8. Zairion, Islamiati, N., Wardiatno, Y., Mashar, A., Wahyudin, R. A., \& Hakim, A. A. 2017. Dinamika Populasi Lobster Pasir (Panulirus homarus ), di Perairan Palabuhanratu, Jawa Barat. Jurnal Penelitian Perikanan Indonesia. 23(3): 215-226. 